\title{
Changing perceptions and usage of public and pseudo-public spaces in the post-pandemic city: the case of Istanbul
}

\author{
Muhammed Ziya Paköz ${ }^{1} \cdot$ Cansu Sözer ${ }^{1} \cdot$ Ayşen Doğan ${ }^{1}$
}

Accepted: 26 November 2020 / Published online: 12 January 2021

(c) The Author(s), under exclusive licence to Springer Nature Limited part of Springer Nature 2021

\begin{abstract}
Public space has critical importance for the city and society because it forms a sense of community. The debate on the end of public space, which is ongoing as the privatization in the city rises, moves on to a new phase with the Covid-19 outbreak. Since the perception of public spaces will be a determinant factor in the future of the city, the question arises: How the perception and usage of the public, virtual public and pseudo-public spaces (particularly shopping malls) have been affected by the recent Covid-19 pandemic? The aim of this study is to examine the changing perception and usage of public and pseudopublic spaces during the Covid-19 outbreak in Istanbul, Turkey. Within this scope, an online survey was conducted with 337 participants living in Istanbul between the dates of 1-5 June 2020. With this survey, the change in perceptions and usage of these spaces based on personal, residential and district characteristics were investigated. The findings of the study revealed statistically significant differences between the perceptions and usage of public spaces and pseudo-public spaces before and after the Covid-19 outbreak in terms of personal, residential and district characteristics. According to survey results, there would be a significant decrease in the frequency of possible visits to public places. The outbreak reduces interest in virtual spaces as a leisure activity, but it also increases the interest in virtual spaces as a shopping and meeting/chat platform. In addition, it was determined that the demand for shopping centres and virtual platforms as both before-after-the-outbreak leisure activities decreased significantly as the amount of green space per capita increases. Besides, the diminishing reputations of pseudo-public spaces and the increasing importance of virtual public spaces may be observed from the survey results. The longer the outbreak, the greater its impact on the design and planning of public spaces and pseudo-public spaces. Rather than planning huge and crowded spaces such as big squares and huge malls, there is likely a shift toward planning a large number of small-scale public spaces within walking distance.
\end{abstract}

Keywords Public space $\cdot$ Pseudo-public space $\cdot$ Virtual public space $\cdot$ The Covid-19 outbreak $\cdot$ Istanbul

\section{Introduction}

The concept of public space, with its simplest definition, refers to the areas where there is a common use right for every individual in society. While the term was first used

Muhammed Ziya Paköz

mzpakoz@gtu.edu.tr

Cansu Sözer

c.sozer@gtu.edu.tr

Ayşen Doğan

aysen.dogan@gtu.edu.tr

1 Department of City and Regional Planning, Faculty of Architecture, Gebze Technical University, 41400 Gebze, Kocaeli, Turkey as "common areas" in the 1960s, it transformed into the concept of "public space" after the 1970s (Dacheux 2012).

From antiquity to the post-modern era, public spaces have always become at the centre of interests, crises, and debates. Especially in the last few decades, the debate on public spaces dramatically increased. After the work of Jurgen Habermas and Hannah Arendt, discussions and evaluations about the concept of public space have been enriched with the contributions of Richard Sennett. The changing meaning and content of public spaces (Madanipour 2019; Pratt 2017; Gak 2016), the blurring boundaries between public and private spaces (Crawford 1999; Ye 2019), the privatization of public spaces (pseudo-public spaces) (Wang and Chen 2018; Bodnar 2015), the increasing importance of virtual public spaces (Fuchs 2017; Dahlgren 2018; Kruse et al. 2018; Miller 2020) are hot topics in the relevant agenda. 
It is clear that the transformations from the agricultural society to the industrial, post-industrial, digital society largely influenced the view on public spaces. However, the Covid-19 outbreak seems to be a turning point that would change the perception and usage of public spaces permanently. The main motivation of this paper is to investigate to what extent the outbreak would change perception and usage of public spaces and pseudo-public spaces; and how personal, residential, and district characteristics affect the perception and usage of these spaces. Within this context, we studied the city of Istanbul as a case by conducting an online survey with 337 participants between the dates of 1-5 June 2020. The investigation constitutes the change in perception and usage of public spaces for multiple purposes (communication, leisure, shopping, etc.) during and after the outbreak. The questionnaire also ensures to examine the change in the usage of shopping malls as pseudo-public spaces and online video platforms as virtual public spaces during and after the outbreak.

The first part of the paper following introduction is devoted to discussion on the changing meaning and usage of public spaces from a historical perspective. This part also consists of studies on public spaces in the city of Istanbul. The second part clarifies the methodology with details in data analysed, statistical methods used, and the study area worked. The third part shares the main findings of the study under the titles of "changes in perception and usage of public spaces', 'changes in the usage of public spaces for leisure activities', 'changes in shopping behaviour', and 'changes in the usage of online video platforms' with brief discussions. The conclusion part consists of general evaluations with recommendations for further studies.

\section{Public space: definitions and recent discussions}

Despite the fact that the debates on the meaning of public space provide a broad perspective, we will present the main approaches very briefly in order to build our study upon it. In his famous book, Weber (1958) defined public space as "the space that is presented or opened to every individual regardless of culture, religion, and even social status". Habermas has examined the concept of public space under the headings of economics, sociology, and politics arguing that public space is embodied by the participation of people (Habermas 1991). Madanipour defines public space physically as areas where individuals freely existed, and symbolically as the fields formed by individual and corporate thoughts (Madanipour 2003). Public space, according to Arendt, is open to everyone, has no limitations, is the place where people come together in harmony (Arendt 1998). According to Sennett, the most important feature of the city is that it is a public space that gives an opportunity to interact with others without hiding personal differences and imposing personal values on someone else. In this context, Richard Sennett tried to clarify this distinction by stating that "the public space is a human creation and the private space is the human condition" (Sennett 1977). Today, public spaces are classified into different areas such as parks, sidewalks, streets, urban squares, recreation areas, and shopping malls. While designing public spaces, the concepts of communicating, navigating in space, and perceiving space should be addressed. A truly quality public space is an area that allows people to listen to a concert, watch a movie, and use it as an office (Riether 2016).

The form and function of public spaces have been transformed during the history. It has always shaped the urban fabric with its functions as a market place, a meeting point, a media for cultural interactions and political debates; and with its different forms as agoras, forums, piazzas, squares, streets, theatres, parks, libraries, coffeehouses (Carr et al. 1992; Madanipour 2003). While its monumental structure and symbolic meaning was at the forefront in the agricultural community (Burgers 1995), it has become a degenerated and exclusive space under the pressure of industrial capitalism (Habermas 1991). Along with the digital society, technology and knowledge have played an active role in the transformation of societies. Public space has been a phenomenon that needs to be reconsidered accordingly (Crang 2000).

Sorkin argues that the digital city has three characteristics: Globalization instead of localization, obsession with security, and simulation. Gated communities reflect this obsession with security, which thought as a consequence of the urban fear (Low 2001), creating isolated groups of people, further reinforcing fear as well as lowering the sense of community (Wilson-Doenges 2000), so the quality of public space, because the sense of community is significantly related with the quality of public spaces (Bibeva 2012; Francis et al. 2012).

\section{Discussions on pseudo-public and virtual public spaces}

In the digital era, the privatization of public spaces (pseudopublic spaces) and the increasing importance of virtual public spaces have become the focus of the discussion on the end of public space. As Langstraat and Van Melik (2013) states any space that is owned and managed by enterprises that only has profit in mind can be considered as pseudopublic space. Plazas and shopping centres are the most common examples of pseudo-public spaces. Unlike other public spaces, virtual public spaces are not restricted to physical boundaries (Arends and Hordijk 2016). These spaces both refer to "the emerging online venues where people could either discuss in groups or be the audience 
of public discussions" (Li 2010) such as social media platforms and online forums, and refer to online shopping and entertainment platforms, which are in pseudo-public character. According to Sorkin, advances in communication and mobility and the new world order defined by "citizenship of consumption" disrupted the city; characteristics of the city, borders, and centres no longer mattered (Sorkin 1992). With the formation of the digital society, the function of public space has been privatized, socialization has decreased and the character of public space has changed. The difference between public and private space has become ambiguous. Shopping malls, which represent the privatization of public spaces, have been considered as pseudo-public spaces as they are seemingly open to all "but they are designed and managed for seeking profit and serving paying customers" (Wang and Chen 2018). It's been argued that as private interests are always at the forefront of the management and control of these areas, although these areas resemble public spaces at first sight, they are therefore not really public (Langstraat and Van Melik 2013). And "... any expectation that such spaces are open to all is fanciful at best." (Banerjee 2001). According to Voyce (2006), the privatized space "reduces and controls diversity". These spaces by design divide and classify people.

Shopping malls are similar to the virtual space in the sense that they are artificial and controlled. The city is invaded by advertisement; shopping malls are full of images and ads, constantly trying to get our attention and to be more memorable. The entertainment industry and social media do the same. There is a constant flow of information and distraction. "Modern individuals are isolated in their office cubicles or assembly line, their cars and suburban homes, and then compensate for this isolation by the shared experience of mass entertainment" (Kohn 2008).

Another important topic in public space discussions is the rise of virtual spaces. In the digital society, virtual space takes on some of the roles physical space used to have. Not only physical access but also representative or sensory access is possible to a public space (Habermas 1991). The embodiment of a public on the internet happens not with the physical forms of people, but with signs and representations, electronic imprints left by people (Li 2010). Social networks, which are described as public spaces, are the areas where individuals come together and create an environment for discussion. This is the product of the information society. Many conveniences are provided over the internet and individuals can meet their needs from new public spaces. However, this rapid change has put the spatial and social structure under pressure. Spatial and social change causes social life to crumble (Varol 2010).

Social media platforms made the distinction between public and private fuzzier. This affects the political function of public space as well. Most recent activist movements are either established in the cyber world or are getting stronger by finding supporters through social media and blogs (Çöteli 2018). Recent Black Lives Matters protests in the US shows that public spaces are still functioning as a medium for democratic rights, supported by social media. However, Mitchell (1995) argues that "material public spaces remain a necessity for (particularly) oppositional political movements."

\section{Rethinking'the end of public space' after the outbreak}

The debates on public spaces in the digital era sometimes lead to the claim of the end of public space. It is also argued that the studies are focused too much on recapitalized city centres and claiming the end of public space is oversimplifying a complex situation, the ideal public space has never existed but public space always "is in the process of becoming through struggle and debate" (Paddison and Sharp 2007). However, the privatized spaces are motivated by profit and designed to keep customers under surveillance. If such places do not herald the end of public space, they do represent "publicity without democracy." (Madden 2010).

The Covid-19 outbreak most likely will affect the evaluations and perceptions of public spaces. The possible effects of Covid-19 on public space have started to be discussed in the literature (Freeman and Eykelbosh 2020; Honey-Roses et al. 2020), while political measures have been taken with the reduction of public space use and social distance restriction with some guidelines and adaptations (Ministry of Housing 2020).

The government in Turkey managed the first phase of the pandemic process with strict restrictions on the use of public spaces similar to many countries. Immediately after the first cases detected in Turkey, face-to-face education was interrupted; and distance education was started in the following two weeks at all levels of education. This implementation was followed by intercity travel restrictions and curfews. The curfew was first imposed for citizens over the age of 65 , and then for young people under 20. Later, curfews on weekends and holidays were imposed for all citizens in metropolitan cities including Istanbul. In this way, it was aimed to keep the number of people infected with the virus to a minimum and prevent its spread. Subsequently, entrance to public places such as picnic areas, national parks, forests and archaeological sites were banned. Shopping centres, cafes, restaurants, cinemas, and beaches were closed. Mass worship was restricted in mosques and masjids. At the same time, sparse seating was introduced in public transport. Along with these restrictions, social and financial support packages were announced for families negatively affected by the pandemic. All these restrictions on the use of public and pseudopublic spaces have been gradually lifted as of June 1, 2020 (AHK Turkey 2020). However, the future of public space 


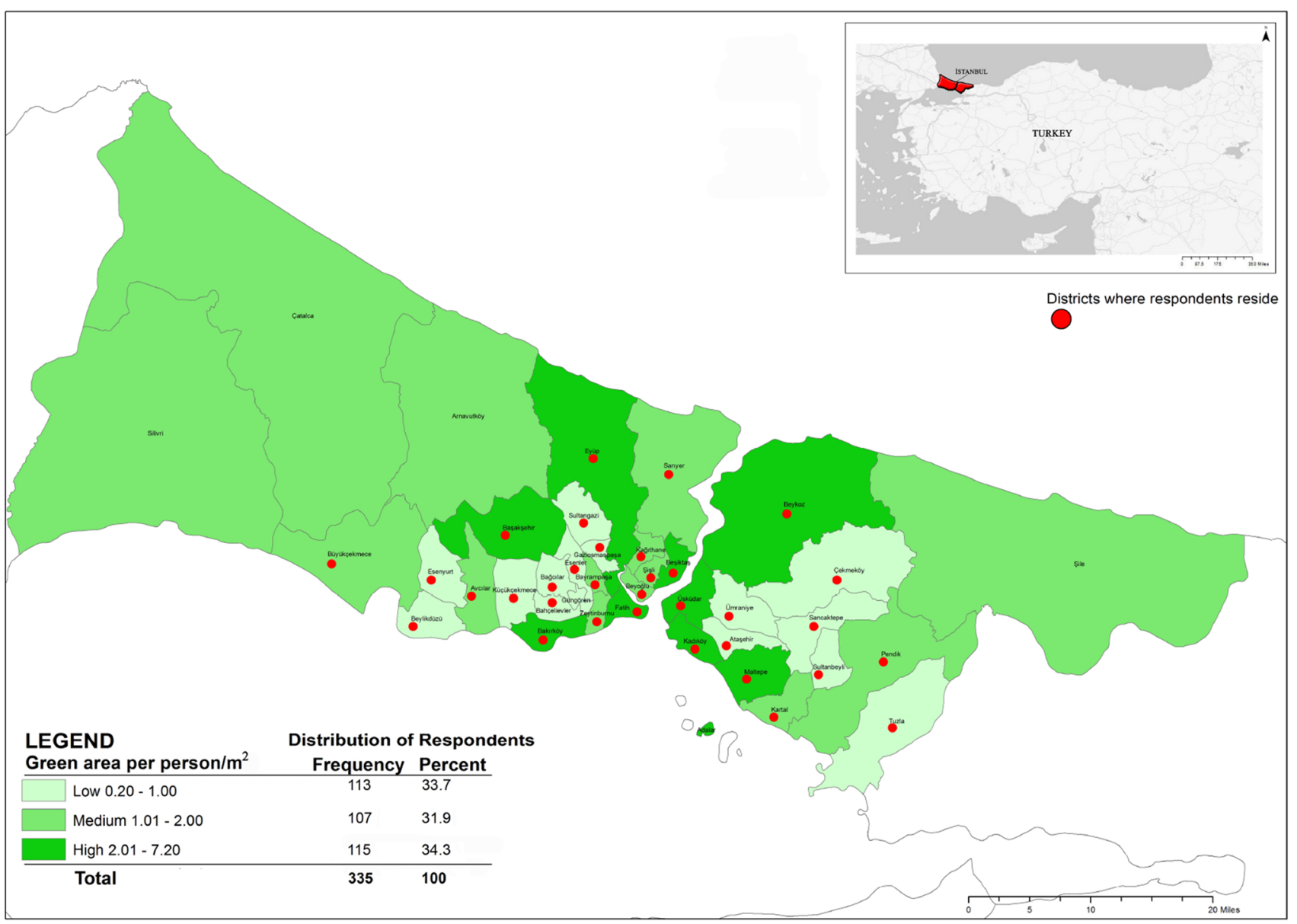

Fig. 1 Distribution of the respondents by districts based on active per capita green area (Produced by authors) Sources: Survey data; active green area per capita by districts (Erginli 2018); the location map (mapstyle.withgoogle.com)

is uncertain and necessitates more researches from different parts of the world. The present study, which is investigating the possible changes in perception and usage of public spaces in the city of Istanbul (Fig. 1), will contribute to the debates on the future of public space in the post-pandemic city.

Istanbul, which is Turkey's socio-economic and cultural centre, has a number of public spaces having the cultural and historical value despite the rapid growth. There have been some studies evaluating and discussing the formation (Karakuyu 2010; Sadri 2017), transformation (Arslanli et al. 2011; Çelebi Gürkan and Özaslan 2019) and spatial quality of public spaces (Saylan and Erdönmez-Dinçer 2017) within the different parts of the city. However, there is a lack of field studies on the usage and perception of public space in Istanbul except for a prominent study (Özgür et al. 2017), which compares two contrasting districts: Ataşehir and Kadiköy. The former is a finance centre mainly consisting of gated communities, referred to as "private space led urbanization" whereas the latter is one of the oldest settlements of Istanbul. The study finds that people living in Ataşehir prefer shopping malls after home to spend their leisure time contrary to Kadıköy in which people have a sense of community. According to the authors, "the primary threat to public spaces in Istanbul is private space-led urbanization, which discourages the flourishing of neighbourhood relations and regular use of local public spaces."

\section{Methodology}

The present study examines the changing perception and usage of public and pseudo-public spaces during the Covid19 outbreak in the city of Istanbul, Turkey. Within this scope, we conducted a statistical analysis using both primary and secondary data. As primary data, we conducted an online survey with 337 participants living within the city of Istanbul between the dates of the 1st and 5th of June $2020^{1}$. The personal characteristics of respondents (age,

\footnotetext{
1 The dates selected for the survey (1-5 June 2020) are the dates the government began easing most of the restrictions on the use of public and pseudo-public spaces. The selected dates are when the par-
} 
Table 1 The datasets used in the statistical analysis

\begin{tabular}{lll}
\hline Data & Source & Type \\
\hline Active green areas per capita by districts & Erginli (2018) & Secondary data \\
Number of shopping malls by districts & CSC (2020) & Secondary data \\
GLA (Gross Leasable Area) of shopping malls by districts & CSC (2020) & Secondary data \\
Total population of districts & TURKSTAT (2019) & Secondary data \\
Personal characteristics of respondents & Survey results & Primary data \\
Residential characteristics & Survey results & Primary data \\
$\begin{array}{l}\text { Evaluation on and usage of public space, pseudo- public space } \\
\text { (shopping malls) and virtual spaces }\end{array}$ & Survey results & Primary data \\
\hline
\end{tabular}

Table 2 Test variables

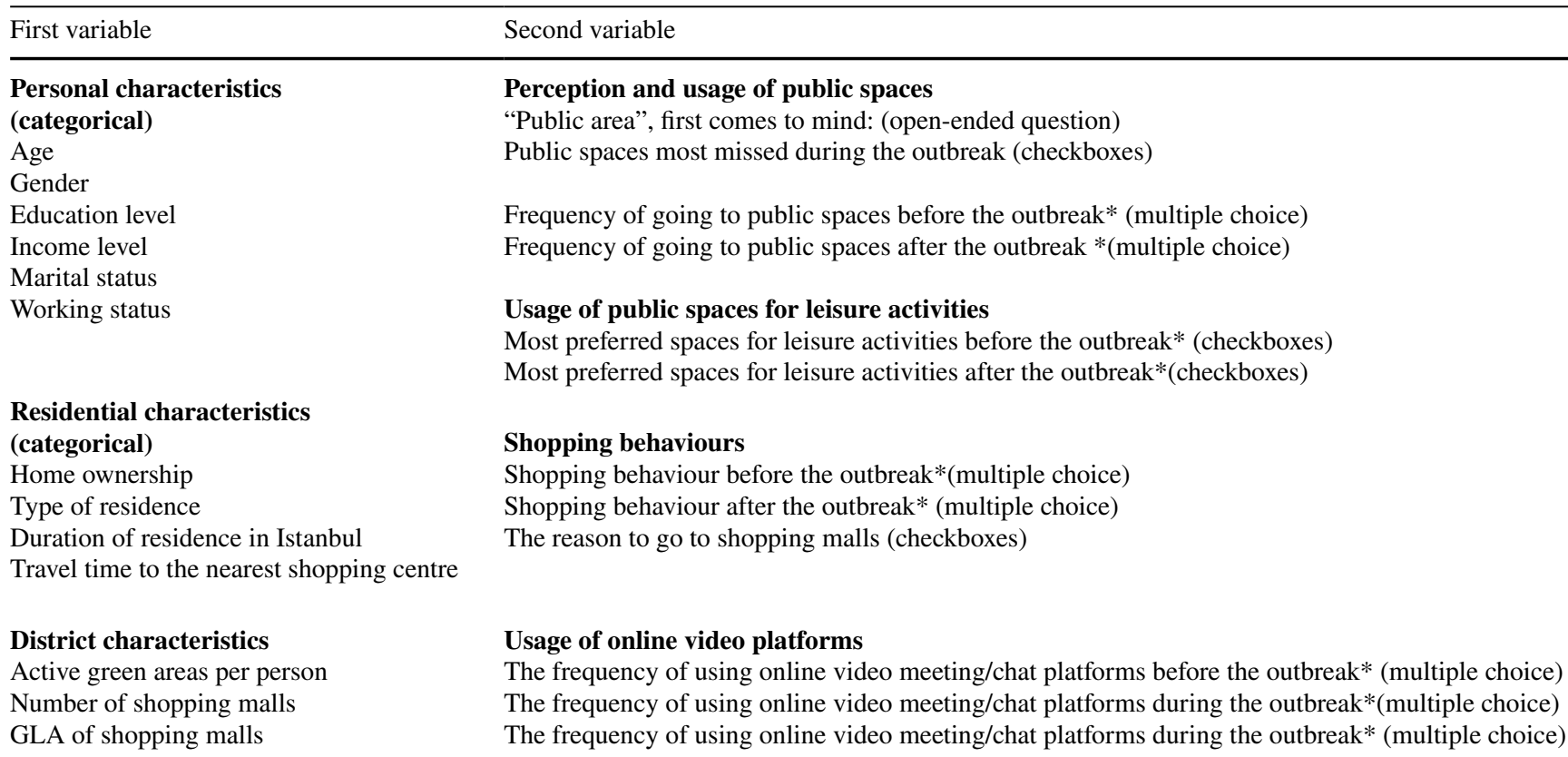

*The questions about the changing behaviours before and after the outbreak are also cross-inquired with each other

gender, income level, education level, marital status, working status, etc.), residential characteristics that they reside in (house ownership, type of residence, duration of residence in Istanbul, etc.) and their usage of public spaces, shopping malls, and online video platforms and their associated evaluations on them are surveyed (Please see Table 2 for a full list of variables). As secondary data, active per capita green area $^{2}$, number and GLA (Gross Leasable Area) of shopping malls, and total population by districts are used (Table 1).

\section{Footnote 1 (continued)}

ticipants recovered from the initial shock effect of the outbreak and began to think more clearly about urban life after the outbreak. Therefore, the dates the survey was conducted are likely to influence the participants' opinions on the questions about the potential usage of public spaces after the outbreak.
These datasets were analysed via SPSS software program to interpret differences between responses of participants in terms of personal, residential, and district characteristics. We statistically tested these differences by Pearson's ChiSquared and the Mantel-Haenszel test of trend (linear-bylinear association). Pearson's Chi-Squared Test measures differences between observed and expected values, however, it doesn't evaluate linear relationships between groups. Besides the chi-square test, to identify the linear relations

\footnotetext{
2 The data of active green areas per capita by districts (Erginli 2018) consists of all active green areas including large spaces like Belgrade Forest. However, only actively used parts of the large open areas are taken into account for calculation. On the other hand, as the general tendency of the residents in Istanbul is to use mostly green spaces within walking distance (Koramaz and Türkoğlu 2014), residents in the districts that have more (small or large) green spaces are considered to have more opportunities to use these green spaces more frequently.
} 
between the groups, we used the Mantel-Haenszel test of trend. Table 2 provides an outline of designed cross-tabulations that are tested within the scope of the paper.

We investigated the changing perception and usage of public spaces by four types of questions:

- General perception and evaluations (regardless of the outbreak).

- Usage of public, pseudo-public and virtual spaces before the outbreak (past tenses).

- Usage of public, pseudo-public and virtual spaces during the outbreak ${ }^{3}$ (present tenses).

- Usage of public, pseudo-public and virtual spaces after the outbreak ${ }^{4}$ (future tenses).

Therefore, we used in the related questions of the questionnaire one of these statements: regardless of the outbreak, before the outbreak, during the outbreak, after the outbreak.

Within the scope of the present study, we examined three aspects of the virtual public space: virtual space as a leisure activity, virtual space as a shopping space, and virtual space as a meeting/chat platform. The main findings of these inquiries are shared in the next section.

\section{Study area}

Istanbul, which is the most crowded and dynamic metropolitan city in Turkey with its official population of 15,519,267 (TURKSTAT 2019), is selected as a study area. The city has been the epicentre of the Covid-19 pandemic in Turkey according to the Ministry of Health since the spread rate of the pandemic was higher than any other city in the country. Therefore, the socio-spatial reflection of the outbreak is expected to be more robust in the city of Istanbul. The city has 39 districts in total. In the study, participants from 33 of these 39 districts answered the questionnaire. The main descriptive statistics derived from the questionnaire are summarized in count and percent in Table 3.

The characteristics of selected districts are categorized into three levels to be able to cross-inquire with the survey results. Considering the number and balanced distribution of samples in each category, we opted for the triple classification (below average, around average and above average), which gave the best results in Pearson's Chi-Squared test and the Mantel-Haenszel trend test. Districts are categorized by per capita active green area as 'less than $1.0 \mathrm{~m}^{2}$, ' $1.1-2.0$ $\mathrm{m}^{2}$, and 'more than $2.0 \mathrm{~m}^{2}$. In the same way, the districts are categorized with respect to the contained number of

\footnotetext{
3 "During the outbreak" refers to the ongoing time period started as of 10 March 2020 when the first case detected in Turkey.

4 "After the outbreak" refers to the future time when all restrictions imposed by Covid-19 will be completely removed.
}

shopping malls as ' $0-1$ malls', ' $2-4$ malls', '5-10 malls' per district (Figs. 1, 2).

\section{Findings and discussion}

\section{Changes in perception and usage of public spaces}

The concept of 'public area/sphere' has a broad range of definitions from totally abstract terms to specialized physical spaces. To be able to figure out which perspectives the participants have, firstly we asked 'the first thing that comes to your mind when you think of public area' to the survey participants in an open-ended question. We grouped 265 answers into 14 categories as open-to-public areas, squares, streets, green areas, beaches, public buildings, hospitals, mosques, cafes, shopping malls, bazaars, social milieu/ interaction, freedom, and respect. Then, we re-grouped the answers according to the level of abstraction and publicness and divided them into 5 groups starting from the most abstract concepts to the most distinct and specialized spaces (Table 4).

As can be seen in Table 4, the general trend in looking at the public area/sphere is in the direction of easy-to-access, public physical spaces. Abstract views such as freedom, social milieu, interaction, respect constitute only $\% 8.3$ of total responses while controversial 'public' (or pseudo-public) spaces (shopping malls) and cafes constitute only $\% 6$ of total responses.

The results from the open-ended question (the first thing that comes to your mind when you think of public area) hints the perception of the public on "the end of public space". The shopping mall only constitutes a small fraction of the total answers even though the majority of the participants can reach at least one shopping mall within 15 min according to the survey. We can say that public space is defined by the majority of participants as easily accessible, open to everyone, and belongs to the public.

The second question was about the most missed public spaces during the outbreak (A checkbox question that allows adding an option not listed). The results reveal that the most missed public space during the outbreak is open green areas (\%72.7 of respondents) while the second one is cafes/restaurants (\%54.9 of respondents) (Table 5).

The statistical analysis and cross-tabulation of the second question reveal that the interest in public spaces differs most by gender in personal characteristics. Among the different places we list as public spaces, city squares appear as public spaces that are least affected by personal (non-spatial) characteristics while cafes and restaurants are very sensitive to these personal characteristics. Women compared to men (gender), singles compared to married people (marital status), young people compared to the elderly (age), and those 
Table 3 Personal and residential characteristics of the survey respondents

\begin{tabular}{|c|c|c|}
\hline Personal characteristics & Frequency & Percent \\
\hline \multicolumn{3}{|l|}{ Gender } \\
\hline Female & 201 & 59.6 \\
\hline Male & 136 & 40.4 \\
\hline Total & 337 & 100 \\
\hline \multicolumn{3}{|l|}{ Age } \\
\hline $15-24$ & 83 & 24.6 \\
\hline $25-34$ & 137 & 40.7 \\
\hline $35-44$ & 59 & 17.5 \\
\hline $45+$ & 58 & 17.2 \\
\hline Total & 337 & 100 \\
\hline \multicolumn{3}{|l|}{ Education level } \\
\hline High school and below & 66 & 19.6 \\
\hline Associate \& undergraduate & 223 & 66.2 \\
\hline Graduate \& postgraduate & 48 & 14.2 \\
\hline Total & 337 & 100 \\
\hline \multicolumn{3}{|l|}{ Income level* (Turkish liras) } \\
\hline 4000 and below ( $588 \$$ and below) & 86 & 25.6 \\
\hline $4001-6000(588-882 \$)$ & 81 & 24.0 \\
\hline $6001-8000(882-1176 \$)$ & 57 & 16.9 \\
\hline $8000+(1176 \$+)$ & 113 & 33.5 \\
\hline Total & 337 & 100 \\
\hline \multicolumn{3}{|l|}{ Marital status } \\
\hline Married & 147 & 43.6 \\
\hline Single & 183 & 54.3 \\
\hline Other & 7 & 2.1 \\
\hline Total & 337 & 100 \\
\hline \multicolumn{3}{|l|}{ Working status } \\
\hline Working & 186 & 55.2 \\
\hline Not working/student & 73 & 21.7 \\
\hline Not working/housewife & 24 & 7.1 \\
\hline Not working/looking for a job & 31 & 9.2 \\
\hline $\begin{array}{l}\text { Not working/sufficient income or } \\
\text { retired }\end{array}$ & 23 & 6.8 \\
\hline Total & 337 & 100 \\
\hline Residential characteristics & Frequency & Percent \\
\hline \multicolumn{3}{|l|}{ Property status of the house } \\
\hline Tenant & 153 & 45.8 \\
\hline House owner & 170 & 50.9 \\
\hline Other & 11 & 3.3 \\
\hline Total & 334 & 100 \\
\hline \multicolumn{3}{|l|}{ Type of residence } \\
\hline Gated community & 58 & 17.4 \\
\hline Apartment & 525 & 75.4 \\
\hline Detached house & 24 & 7.2 \\
\hline Total & 334 & 100 \\
\hline \multicolumn{3}{|l|}{ Duration of residence in Istanbul } \\
\hline Less than 1 year & 11 & 3.3 \\
\hline $2-5$ & 36 & 10.7 \\
\hline $6-10$ & 41 & 12.2 \\
\hline
\end{tabular}

\begin{tabular}{lcl}
\hline Residential characteristics & Frequency & Percent \\
\hline $11-15$ & 29 & 8.6 \\
$16-19$ & 16 & 4.7 \\
$20+$ & 204 & 60.5 \\
Total & 337 & 100 \\
\hline
\end{tabular}

*The equivalents of income levels in USD are calculated based on exchange rates on June 1, 2020

in the high-income group compared to those in the lowincome group (income groups) miss cafes and restaurants more. This indicates that access to cafes and restaurants is related to not only spatial dimensions but also non-spatial restrictions such as free time and budget.

The third question of inquiry was whether Covid-19 would affect the frequency of going to public spaces. The results reveal that there is a statistically significant difference between the frequency of going to public spaces before and after the outbreak. As seen in Table 6, while $67.1 \%$ of the participants go to public places several times a week before the outbreak, it is seen that this rate would decrease to $41.5 \%$ after the outbreak according to the responses. This indicates that the effect of the trauma caused by the pandemic on public spaces will continue for a long time.

There is no significant difference between the usage of public spaces before and after the outbreak in terms of residential and personal characteristics except "gender" (Table 6). A sharper decrease is observed in the frequency of women using public spaces after the outbreak as compared to men. It shows that the pandemic has more negative effects on women in their uses of public spaces.

We also inquired how the district characteristics would influence the frequency of usage of public spaces before and after the outbreak. As we stated in the methodology part, we classified districts according to active green areas per capita (as $<1.0 \mathrm{~m}^{2} / 1.1-2.0 \mathrm{~m}^{2} />2.0 \mathrm{~m}^{2}$ ) and according to number of shopping malls (as 0-1 malls/2-4 malls/5-10 malls). Then, we cross-tabulated the district characteristics with the frequency of usage of public spaces before and after the outbreak. The results reveal that there is a significant difference between districts, which is classified by active green areas per person and number of shopping malls, and the usage of public spaces before and after the outbreak (Table 7). While the frequency of going to public spaces is increasing in the districts with more green areas per capita, the frequency of going to public spaces is decreasing in the districts with the high number of shopping centres both before and after the outbreak. In addition, it is observed that the frequency of visiting public spaces after the outbreak has decreased much more in districts with a higher number of shopping malls and in districts with less green areas per capita than others. This reveals the 
diminishing reputation of shopping malls, while open green spaces come to the fore as public spaces after the outbreak. Therefore, it is possible to say according to the survey results that the Covid-19 outbreak is likely to empower the public claim on the real public spaces in Istanbul.

\section{Changes in the use of public spaces for leisure activities}

The findings about the most preferred spaces for leisure activities before and after the outbreak are also in favour of the argument about the diminishing reputation of shopping

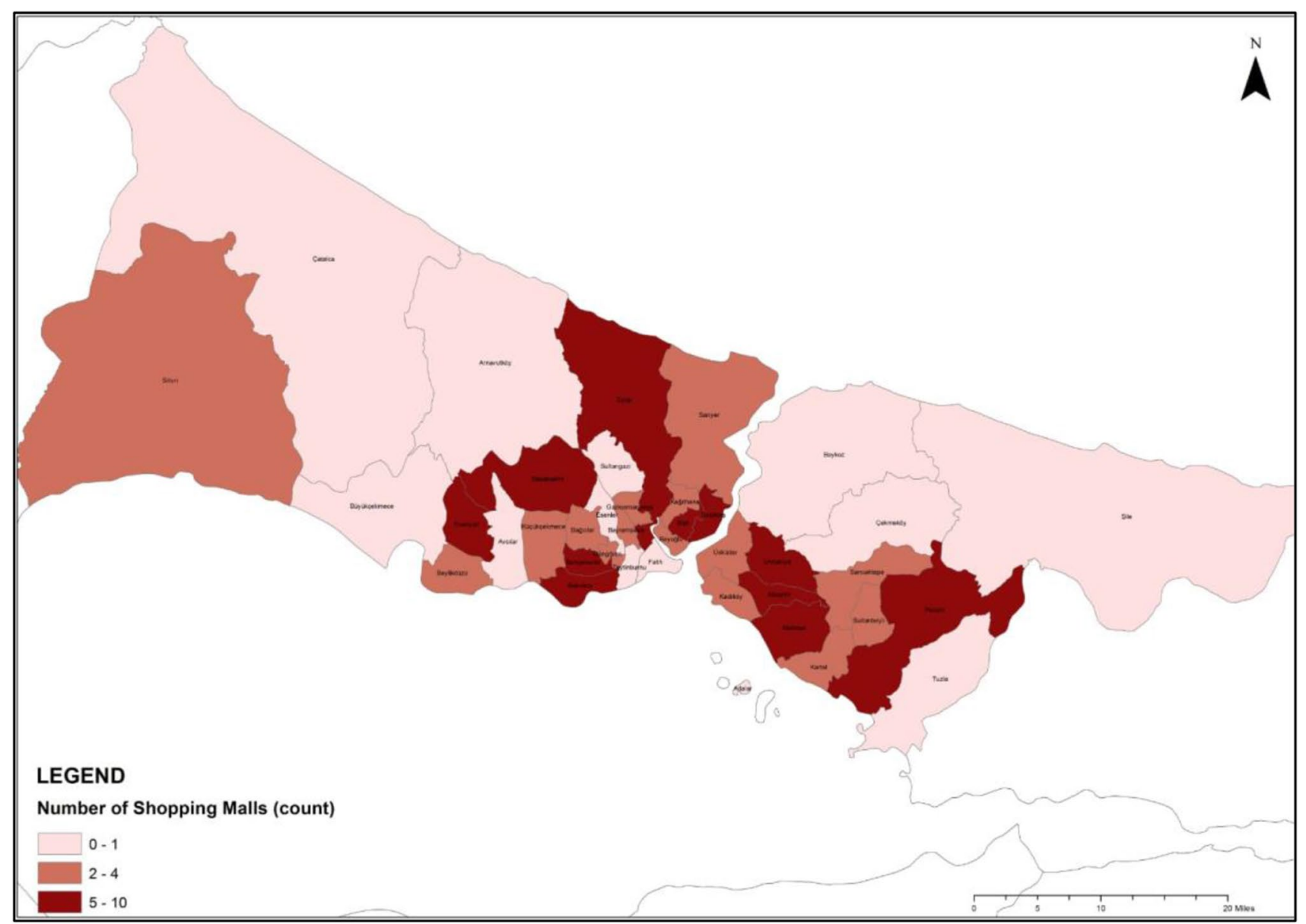

Fig. 2 Districts by contained number of shopping malls (Produced by authors based on data of 'address and GLA of shopping malls' (CSC 2020)

Table 4 The distribution of responses on the interpretation of 'public area'

\begin{tabular}{llcl}
\hline Level of abstraction & "Public area", the first thing that comes to mind is: & Frequency & Percent \\
\hline 1 & Social milieu, interaction, respect, freedom, etc & 22 & 8.3 \\
2 & Open-to-public area & 68 & 25.7 \\
3 & Square, park (green area), beach, street, bazaar & 125 & 47.2 \\
4 & Public buildings & 34 & 12.8 \\
5 & Cafe, mall & 16 & 6.0 \\
Valid cases & & 265 & 100 \\
Missing cases (no response for this question) & 72 & \\
\hline
\end{tabular}


Table 5 The most missed public spaces during the outbreak by personal characteristics

\begin{tabular}{|c|c|c|c|c|c|c|c|}
\hline$N$ (Valid cases): 337 & The percentage of & Personal & haracteris & affecting the ' $m$ & ng level' of PS & & \\
\hline City squares & 30.3 & & & & & & \\
\hline Shopping malls & 23.4 & & $\begin{array}{l}\text { Gender } \\
0.020^{*}\end{array}$ & $\begin{array}{l}\text { Education level } \\
0.006^{*} \\
0.040^{* *}\end{array}$ & & & \\
\hline Open green areas & 72.7 & & $\begin{array}{l}\text { Gender } \\
0.003 *\end{array}$ & & & & \\
\hline Café \& restaurants & 54.9 & $\begin{array}{l}\text { Age } \\
0.000 * \\
0.000 * *\end{array}$ & $\begin{array}{l}\text { Gender } \\
0.000^{*}\end{array}$ & $\begin{array}{l}\text { Education level } \\
0.055^{*} \\
0.017^{* *}\end{array}$ & $\begin{array}{l}\text { Income level } \\
0.020^{*} \\
0.018^{* *}\end{array}$ & $\begin{array}{l}\text { Marital status } \\
0.004 *\end{array}$ & $\begin{array}{l}\text { Working status } \\
0.032 * \\
0.049 * *\end{array}$ \\
\hline Religious facilities & 20.5 & & $\begin{array}{l}\text { Gender } \\
0.000^{*}\end{array}$ & & & $\begin{array}{l}\text { Marital status } \\
0.017 *\end{array}$ & \\
\hline Entertainment facilities & 16.6 & $\begin{array}{l}\text { Age } \\
0.004 * \\
0.000 * *\end{array}$ & & & & & \\
\hline Other & 2.7 & & & & & & \\
\hline
\end{tabular}

*Significant at 0.01/0.05 level (Pearson chi-squared)

**Significant at 0.01/0.05 level (Linear-by-linear association)

Table 6 The change in the frequency of going to public spaces before and after the outbreak by gender differences

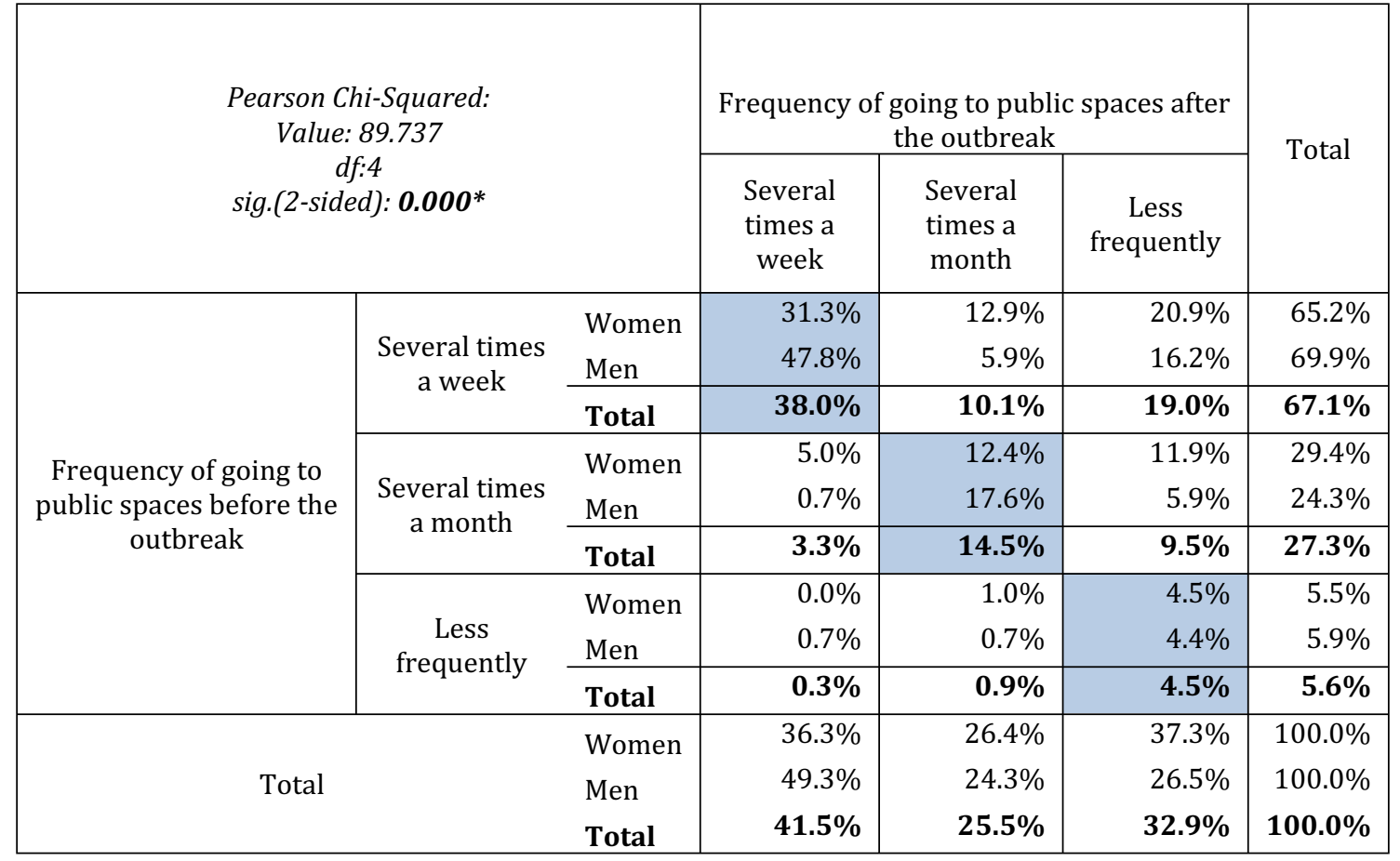

*Significant at 0.01 level

**In the table, the blue-shaded areas show the percentage that there is no expected change in the frequency of going to public spaces after the outbreak

malls. We asked participants to mark one or more preferred spaces from the following list for their leisure activities ${ }^{5}$ :

\footnotetext{
5 We asked two different questions for the most preferred leisuretime spaces: 1. Most preferred spaces for leisure activities before the
}

\section{Footnote 5 (continued)}

Covid-19 pandemic. 2. Most would be preferred spaces for leisure activities after the Covid-19 pandemic. 
Table 7 The change in the rate of most frequent visitors of public spaces after the outbreak

\begin{tabular}{|c|c|c|c|c|}
\hline & & $\begin{array}{l}\text { Before the outbreak } \\
\text { Several times a week }\end{array}$ & After the outbreak & Change (\%) \\
\hline \multirow{3}{*}{$\begin{array}{l}\text { Number of shopping malls } \\
\text { by district }\end{array}$} & $0-1$ malls & $76.2 \%$ & $65.1 \%$ & -14.6 \\
\hline & 2-4 malls & $67.9 \%$ & $37.9 \%$ & -44.2 \\
\hline & 5-10 malls & $61.4 \%$ & $34.1 \%$ & -44.4 \\
\hline Pearson chi-square & & 0.310 & $0.001 *$ & \\
\hline $\begin{array}{l}\text { Linear-by-linear associa- } \\
\text { tion }\end{array}$ & & $0.031 * *$ & $0.000 *$ & \\
\hline \multirow{3}{*}{$\begin{array}{l}\text { Active green areas per } \\
\text { capita by district }\end{array}$} & $0-1.0 \mathrm{~m}^{2}$ & $61.1 \%$ & $30.1 \%$ & -50.7 \\
\hline & $1.1-2.0 \mathrm{~m}^{2}$ & $66.4 \%$ & $46.7 \%$ & -29.6 \\
\hline & $>2.0 \mathrm{~m}^{2}$ & $73.0 \%$ & $47.8 \%$ & -34.5 \\
\hline Pearson chi-square & & 0.248 & 0.055 & \\
\hline $\begin{array}{l}\text { Linear-by-linear associa- } \\
\text { tion }\end{array}$ & & $0.040 * *$ & $0.009 *$ & \\
\hline
\end{tabular}

*Significant at 0.01 level

**Significant at 0.05 level

- Home.

- Virtual space.

- Historical and cultural spaces.

- Shopping malls.

- Market and bazaar.

- Urban recreation spaces.

- Other.

We cross-inquired the responses with the district characteristics (green area per person \& number of shopping malls) again. The results reveal that as the amount of active green area per capita in the districts increases, the rate of choosing virtual spaces and shopping malls for leisure decreases significantly (both before and after the outbreak). On the other hand, as the number of shopping malls in districts increases, there is no significant increase in the use of shopping malls in leisure. In addition, after the pandemic, the preference rate of shopping malls seems to decrease by $61 \%$, while the preference rate for open green areas seems to increase by $33.3 \%$. After the pandemic, although there is a tendency of a decrease in the use of places other than the open green area, the highest decrease in the ratio is again in the shopping malls (Table 8).

\section{Changes in shopping behaviours}

As the Covid-19 outbreak has caused many residents to change their habits for a short time or completely, it is also seen that shopping habits have started to take shape according to the post-pandemic city. Within the scope of this study, we asked participants how they mostly used to meet their shopping needs before the outbreak and how they plan to meet their shopping needs after the outbreak. The results show that the rate of online shopping in total before the outbreak was $19.5 \%$, while this rate has increased to $45.3 \%$ after the outbreak. However, as seen in Table 9, this increase is mostly due to the decrease in the share of the shopping mall, because the rates of bazaar shopping in total shopping before and after the outbreak is almost same. Thus, we can say that online shopping will largely replace shopping malls after the outbreak.

The change in shopping behaviour is also cross-inquired with the personal characteristics of the respondents. It is seen that shopping behaviour is very sensitive to personal characteristics (See Table 10). The survey results show that age, education level, and income level significantly affect shopping behaviour both before and after the outbreak. However, the most effective factor influencing shopping behaviour seems to be 'age' $\left(\chi^{2}: 0.000\right)$. Before the outbreak, young people under the age of 35 seemed to be more likely to shop at the mall, while participants over 35 often seem to prefer bazaar. After the outbreak, the preference of the youth has shifted from shopping malls to online shopping, while there is not much change in the choice of people over the age of 35 .

Within the survey, we also investigated the reason to go to shopping malls (regardless of the outbreak) by asking to choose one or more of the following choices:

- Shopping.

- Cinema \& culture.

- Entertainment.

- Eating \& drinking.

- Spending time with family and friends.

Despite the fact that the main motivation to go to the malls is shopping, we can state that many people have 
Table 8 The most preferred spaces for leisure activities before and after the outbreak

\begin{tabular}{|c|c|c|c|c|c|c|}
\hline & \multicolumn{6}{|c|}{ Most preferred spaces for leisure activities before the Covid-19 pandemic } \\
\hline & Home & Virtual space & $\begin{array}{l}\text { Historical and } \\
\text { cultural spaces }\end{array}$ & Shopping malls & $\begin{array}{l}\text { Market and } \\
\text { bazaar }\end{array}$ & $\begin{array}{l}\text { Urban } \\
\text { recreation } \\
\text { spaces }\end{array}$ \\
\hline \multicolumn{7}{|c|}{ Active green space per person by district } \\
\hline$<1.0 \mathrm{~m}^{2}$ & $55.8 \%$ & $27.4 \%$ & $30.1 \%$ & $43.4 \%$ & $42.5 \%$ & $53.1 \%$ \\
\hline $1.1 \mathrm{~m}^{2}-2.0 \mathrm{~m}^{2}$ & $67.3 \%$ & $29.9 \%$ & $25.2 \%$ & $42.1 \%$ & $40.2 \%$ & $54.2 \%$ \\
\hline$>2.0 \mathrm{~m}^{2}$ & $67.0 \%$ & $11.3 \%$ & $28.7 \%$ & $25.2 \%$ & $36.5 \%$ & $61.7 \%$ \\
\hline Pearson & 0.125 & $0.001 *$ & 0.713 & $0.007 *$ & 0.650 & 0.360 \\
\hline Linear-by-linear association & 0.081 & $0.004 *$ & 0.818 & $0.004^{*}$ & 0.358 & 0.188 \\
\hline \multicolumn{7}{|c|}{ Number of shopping malls by district } \\
\hline $0-1$ malls & $63.5 \%$ & $19.0 \%$ & $19.0 \%$ & $30.2 \%$ & $46.0 \%$ & $50.8 \%$ \\
\hline $2-4$ malls & $61.4 \%$ & $19.3 \%$ & $27.1 \%$ & $42.1 \%$ & $42.9 \%$ & $60.0 \%$ \\
\hline 5-10 malls & $65.2 \%$ & $28.0 \%$ & $33.3 \%$ & $34.1 \%$ & $33.3 \%$ & $55.3 \%$ \\
\hline Pearson & 0.816 & 0.170 & 0.110 & 0.189 & 0.144 & 0.448 \\
\hline Linear-by-linear association & 0.816 & 0.097 & $0.037 * *$ & 0.918 & 0.060 & 0.756 \\
\hline \multirow[t]{3}{*}{$N$ (Valid cases): 335} & 212 & 76 & 94 & 123 & 133 & 189 \\
\hline & \multicolumn{6}{|c|}{ Most would be preferred spaces for leisure activities after the Covid-19 pandemic } \\
\hline & Home & Virtual space & $\begin{array}{l}\text { Historical and } \\
\text { cultural spaces }\end{array}$ & Shopping malls & $\begin{array}{l}\text { Market and } \\
\text { bazaar }\end{array}$ & $\begin{array}{l}\text { Urban } \\
\text { recreation } \\
\text { spaces }\end{array}$ \\
\hline \multicolumn{7}{|c|}{ Active green space per person by district } \\
\hline$<1.0 \mathrm{~m}^{2}$ & $40.7 \%$ & $14.2 \%$ & $31.9 \%$ & $22.1 \%$ & $28.3 \%$ & $77.0 \%$ \\
\hline $1.1 \mathrm{~m}^{2}-2.0 \mathrm{~m}^{2}$ & $39.3 \%$ & $15.9 \%$ & $22.4 \%$ & $13.1 \%$ & $22.4 \%$ & $73.8 \%$ \\
\hline$>2.0 \mathrm{~m}^{2}$ & $39.1 \%$ & $5.2 \%$ & $29.6 \%$ & $7.8 \%$ & $18.3 \%$ & $74.8 \%$ \\
\hline Pearson & 0.964 & $0.028 * *$ & 0.270 & $0.008^{*}$ & 0.194 & 0.855 \\
\hline Linear-by-linear association & 0.808 & $0.035 * *$ & 0.706 & $0.002 *$ & 0.072 & 0.701 \\
\hline \multicolumn{7}{|c|}{ Number of shopping malls by district } \\
\hline $0-1$ malls & $33.3 \%$ & $6.3 \%$ & $28.6 \%$ & $11.1 \%$ & $27.0 \%$ & $66.7 \%$ \\
\hline $2-4$ malls & $35.0 \%$ & $6.4 \%$ & $25.7 \%$ & $16.4 \%$ & $24.3 \%$ & $81.4 \%$ \\
\hline 5-10 malls & $47.7 \%$ & $19.7 \%$ & $30.3 \%$ & $13.6 \%$ & $19.7 \%$ & $72.7 \%$ \\
\hline Pearson & 0.052 & $0.001 *$ & 0.698 & 0.581 & 0.470 & 0.055 \\
\hline Linear-by-linear association & $0.027 *$ & $0.001 *$ & 0.663 & 0.813 & 0.226 & 0.718 \\
\hline$N$ (Valid cases): 335 & 133 & 39 & 94 & 48 & 77 & 252 \\
\hline
\end{tabular}

*Significant at 0.01 level

**Significant at 0.05 level

multiple purposes to go to the shopping malls. These purposes differ significantly with personal characteristics as below:

Shopping: gender.

Cinema \& culture: age, gender, income level, marital status.

Entertainment: age, education level.

Eating \& drinking: age, gender, marital status.

Family \& friends: age, gender, working status, income level, education level, marital status.

As seen, the purpose of 'spending time with family and friends' is mostly affected by personal characteristics.
However, 'age' is the most significant factor affecting the reason for going to shopping malls (Table 11). The rate of the secondary purposes (such as cinema \& culture, eating $\&$ drinking) significantly increases as the age gets younger. Therefore, we can say that shopping malls mean more to young people than shopping (regardless of the outbreak). However, as we abovementioned, because the shopping behaviour of youth is subject to change after the outbreak, the malls are most likely to lose their most important customers.

We also cross-inquired 'the motivation to go to the malls' with residential and district characteristics. While residential characteristics do not have a significant effect on the change of 
Table 9 The change in shopping behaviour after the outbreak

\begin{tabular}{|c|c|c|c|c|c|c|}
\hline \multirow{2}{*}{\multicolumn{3}{|c|}{$\begin{array}{c}\text { Pearson Chi-Squared: } \\
\text { Value: } 155.100 \\
\text { df:4 } \\
\text { sig.(2-sided): } 0.000^{*}\end{array}$}} & \multicolumn{3}{|c|}{$\begin{array}{c}\text { How do you plan to meet your } \\
\text { shopping need after the outbreak? }\end{array}$} & \multirow{3}{*}{$\begin{array}{r}\text { Total } \\
64\end{array}$} \\
\hline & & & $\begin{array}{c}\text { Online } \\
\text { shopping }\end{array}$ & $\begin{array}{c}\text { Shopping } \\
\text { mall }\end{array}$ & Bazaar & \\
\hline \multirow{6}{*}{$\begin{array}{c}\text { How did } \\
\text { you meet } \\
\text { your } \\
\text { shopping } \\
\text { need } \\
\text { MOSTLY } \\
\text { before the } \\
\text { outbreak? }\end{array}$} & \multirow{2}{*}{$\begin{array}{l}\text { Online } \\
\text { shopping }\end{array}$} & Count & 49 & 4 & 11 & \\
\hline & & $\%$ of Total & $14.9 \%$ & $1.2 \%$ & $3.3 \%$ & $19.5 \%$ \\
\hline & \multirow{2}{*}{$\begin{array}{l}\text { Shopping } \\
\text { mall }\end{array}$} & Count & 67 & 57 & 16 & 140 \\
\hline & & $\%$ of Total & $20.4 \%$ & $17.3 \%$ & $4.9 \%$ & $42.6 \%$ \\
\hline & \multirow{2}{*}{ Bazaar } & Count & 33 & 3 & 89 & 125 \\
\hline & & $\%$ of Total & $10.0 \%$ & $0.9 \%$ & $27.1 \%$ & $38.0 \%$ \\
\hline \multirow{2}{*}{\multicolumn{2}{|c|}{ Total }} & Count & 149 & 64 & 116 & 329 \\
\hline & & $\%$ of Total & $45.3 \%$ & $19.5 \%$ & $35.3 \%$ & $100.0 \%$ \\
\hline
\end{tabular}

*Significant at 0.01 level

**In the table, the blue-shaded areas show the frequency and percentage that there is no expected change in shopping behaviour after the outbreak

Table 10 The change in shopping behaviour according to personal characteristics

\begin{tabular}{|c|c|c|c|c|c|c|c|c|}
\hline & \multicolumn{3}{|c|}{ Before the outbreak } & \multirow[t]{2}{*}{ Sig } & \multicolumn{3}{|l|}{ After the outbreak } & \multirow[t]{2}{*}{ Sig } \\
\hline & Online shopping & Shopping mall & Bazaar & & Online shopping & Shopping mall & Bazaar & \\
\hline Age & $25-34$ & $15-24$ & $35-44$ & $\begin{array}{l}0.000 \\
0.000\end{array}$ & $25-34$ & $15-24$ & $45+$ & $\begin{array}{l}0.000 \\
0.000\end{array}$ \\
\hline Gender & Woman & Woman & Man & $\begin{array}{l}0.265 \\
0.114\end{array}$ & Woman & Man & Man & $\begin{array}{l}0.114 \\
\mathbf{0 . 0 4 3}\end{array}$ \\
\hline Income level & High & Upper-middle & Lower-middle & $\begin{array}{l}0.048 \\
0.021\end{array}$ & Upper-middle & Upper-middle & Low & $\begin{array}{l}0.237 \\
\mathbf{0 . 0 3 4}\end{array}$ \\
\hline Education level & Post/graduate & $\begin{array}{l}\text { High-school or } \\
\quad \text { less }\end{array}$ & $\begin{array}{l}\text { High-school or } \\
\quad \text { less }\end{array}$ & $\begin{array}{l}\mathbf{0 . 0 1 3} \\
0.557\end{array}$ & Under-graduate & $\begin{array}{l}\text { High-school or } \\
\text { less }\end{array}$ & $\begin{array}{l}\text { High-school or } \\
\text { less }\end{array}$ & $\begin{array}{l}0.040 \\
0.092\end{array}$ \\
\hline Marital status & Single & Single & Married & $\begin{array}{l}0.020 \\
0.012\end{array}$ & Single & Single & Married & $\begin{array}{l}0.208 \\
0.172\end{array}$ \\
\hline Working status & Not working & Working & Not working & $\begin{array}{l}0.890 \\
0.894\end{array}$ & Working & Working & Not working & $\begin{array}{l}0.315 \\
0.284\end{array}$ \\
\hline
\end{tabular}

*The sub-groups written in the boxes show the groups that prefer that type of shopping the most. The text in bold shows the groups that have a statistically significant difference by at least one of the tests (Pearson/LLA)

this motivation, district characteristics show different behaviours in terms of the motivation to go to the malls. As the district's green area per capita decreases, it is observed that the tendency of the participants to go to the shopping mall for 'eating \& drinking' and 'spending time with family and friends' has increased significantly. On the other hand, it is observed that the number of malls in districts does not change this motivation significantly. Thus, the survey results aforementioned supports the argument that not the existence of malls but the absence of green spaces urges people to go to shopping malls for multiple purposes apart from the meeting of shopping needs.

\section{Changes in the usage of online platforms}

The last investigation in the study is the changes in the frequency of using online video meeting/chat platforms beforeduring-after the outbreak. This investigation is crucial since it provides clues to what extent the transition between physical public spaces and virtual public spaces will be observed in the post-pandemic city.

The digital age, which is we live in, already enforces citizens to change the nature of their relationship and move their business, friendship, meetings, and leisure activities from physical spaces to virtual spaces. The Covid-19 outbreak 
Table 11 The change in the reason to go to shopping malls by age

\begin{tabular}{llllll}
\hline Age & Shopping & $\begin{array}{l}\text { Cinema } \\
\text { and } \\
\text { culture }\end{array}$ & Entertainment & Eating \& drinking & Family \& friends \\
\hline $15-24$ & $80.8 \%$ & $67.9 \%$ & $23.1 \%$ & $64.1 \%$ & $39.3 \%$ \\
$25-34$ & $84.2 \%$ & $60.2 \%$ & $19.5 \%$ & $52.6 \%$ & $32.3 \%$ \\
$35-44$ & $89.3 \%$ & $35.7 \%$ & $10.7 \%$ & $42.9 \%$ & $30.4 \%$ \\
$45+$ & $86.8 \%$ & $30.2 \%$ & $7.5 \%$ & $30.2 \%$ & $20.8 \%$ \\
Pearson & 0.564 & $\mathbf{0 . 0 0 0 *}$ & 0.055 & $\mathbf{0 . 0 0 1 *}$ & $\mathbf{0 . 0 0 0 *}$ \\
Linear-by-linear association & 0.226 & $\mathbf{0 . 0 0 0 *}$ & $\mathbf{0 . 0 0 7 *}$ & $\mathbf{0 . 0 0 0 *}$ & $\mathbf{0 . 0 0 0 *}$ \\
N (valid cases): 320 & $84.7 \%$ & $52.8 \%$ & $16.9 \%$ & $50.0 \%$ & $36.6 \%$ \\
& 271 & 169 & 54 & 160 & 117 \\
\hline
\end{tabular}

*Significant at 0.01 level accelerated this process as expected due to the restrictions on the usage of public and pseudo-public spaces in the first phase of the outbreak. The survey results reveal that there is a significant shift towards using online video meeting/chat programs during the outbreak (Table 12).

The responses also indicate that a significant part of the participants think that this shift would be permanent in the post-pandemic city (Table 13). The other important finding of the survey is that while there was a significant difference between age groups in terms of frequency of using online video meeting/chat platforms before the outbreak $\left(\chi^{2}: 0,003\right.$; LLA:0,006) (young people tend to use online platforms more than older people), there is no significant difference between age groups in terms of frequency of using online video meeting/ chat platforms after the outbreak $\left(\chi^{2}: 0,243\right.$ LLA:0,442). This suggests that due to the Covid-19 outbreak accustomed adults and elderly people to use virtual video platforms, and it largely eliminated age differences in using online video platforms.

\section{Conclusion}

The change in perception and usage of public spaces during and after the Covid-19 outbreak in Istanbul, which was chosen as the study area, was investigated by a survey conducted with 337 participants within the present study. The findings related to the effects of the pandemic process on the use and perception of public space and the differentiation of this effect according to personal, residential, and district features are presented. In the analyses made, how public spaces are perceived and how this perception and usage changed during the outbreak was questioned through the thesis of "end of public space" which is widely discussed in academia. At the same time, the change in the use of shopping malls as pseudo-public spaces and online platforms as virtual spaces was discussed during the pandemic process.

In the first 3 months of the outbreak (until early June), access to public spaces was restricted in order to reduce the
Table 12 The change in the usage of online video meeting/chat platforms

\begin{tabular}{llll}
\hline & $\begin{array}{l}\text { Before the } \\
\text { outbreak }(\%)\end{array}$ & $\begin{array}{l}\text { During the } \\
\text { outbreak }(\%)\end{array}$ & $\begin{array}{l}\text { After the } \\
\text { outbreak }(\%)\end{array}$ \\
\hline Yes, frequently & 33.2 & 79.5 & 52.5 \\
Yes, rarely & 56.4 & 15.7 & 43.6 \\
No & 10.4 & 4.8 & 3.9 \\
Total $(N=337)$ & 100 & 100 & 100 \\
\hline
\end{tabular}

spread rate of the outbreak. This process has been found to increase the longing for public spaces, especially open and green spaces. However, according to the survey results, it is seen that there will be a significant decrease in the frequency of possible visits to public spaces after the outbreak. In addition, there will be a sharper decrease in the use of public space by women compared to men. The anxiety created by the outbreak will increase the power to change the perception and usage rate of public places as time goes on. It is likely that the approaches, which define public space as a space that is freely used without restrictions, are renegotiated in this pandemic that affects cities economically, physically, and socially. On the other hand, new fictions that replace 'physical access' by 'representative access' (with signs, representations, and electronic imprints) would start to appear frequently.

In the study, the perception regardless of the outbreak and the changing perception after the outbreak were measured for shopping malls as pseudo-public spaces. Regardless of the outbreak, most of the public areas that come to mind are physical and city-related: squares, parks, beaches, streets, and bazaars. The level of perception of shopping malls as a 'public area' is far behind these places. On the other hand, to measure whether the use of the shopping centre, that is, pseudo-public space, is caused by the lack of 'real public spaces', comparisons were made between the number of shopping malls and the amount of active green spaces and 
Table 13 The change in the frequency of using online video meeting/chat platforms after the outbreak

\begin{tabular}{|c|c|c|c|c|c|c|}
\hline \multirow{2}{*}{\multicolumn{3}{|c|}{$\begin{array}{c}\text { Pearson Chi-Squared: } \\
\text { Value: } 74.852 \\
\text { df: } 4 \\
\text { sig.(2-sided): } 0.000^{*}\end{array}$}} & \multicolumn{3}{|c|}{$\begin{array}{c}\text { The frequency of using online } \\
\text { video meeting / chat platforms } \\
\text { after the outbreak }\end{array}$} & \multirow[t]{2}{*}{ Total } \\
\hline & & & $\begin{array}{c}\text { Yes. } \\
\text { frequently }\end{array}$ & $\begin{array}{l}\text { Yes. } \\
\text { rarely }\end{array}$ & No & \\
\hline \multirow{5}{*}{$\begin{array}{c}\text { The frequency } \\
\text { of using online } \\
\text { video meeting } \\
\text { / chat } \\
\text { platforms } \\
\text { before the } \\
\text { outbreak }\end{array}$} & \multirow{2}{*}{$\begin{array}{c}\text { Yes. } \\
\text { frequently }\end{array}$} & Count & 86 & 25 & 1 & 112 \\
\hline & & $\%$ of Total & $25.5 \%$ & $7.4 \%$ & $0.3 \%$ & $33.2 \%$ \\
\hline & \multirow{2}{*}{ Yes. rarely } & Count & 82 & 104 & 4 & 190 \\
\hline & & $\%$ of Total & $24.3 \%$ & $30.9 \%$ & $1.2 \%$ & $56.4 \%$ \\
\hline & No & $\begin{array}{l}\text { Count } \\
\% \text { of Total }\end{array}$ & $\begin{array}{r}9 \\
2.7 \% \\
\end{array}$ & $\begin{array}{r}18 \\
5.3 \% \\
\end{array}$ & $\begin{array}{r}8 \\
2.4 \%\end{array}$ & $\begin{array}{r}35 \\
10.4 \% \\
\end{array}$ \\
\hline \multirow{2}{*}{\multicolumn{2}{|c|}{ Total }} & Count & 177 & 147 & 13 & 337 \\
\hline & & $\%$ of Total & $52.5 \%$ & $43.6 \%$ & $3.9 \%$ & $100.0 \%$ \\
\hline
\end{tabular}

*Significant at 0.01 level

**In the table, the blue-shaded areas show the frequency and percentage that there is no expected change in the frequency of using online video meeting/chat platforms after the outbreak

the use of public spaces in districts. Accordingly, it was determined that the demand for shopping malls and virtual platforms as both before-after-the-outbreak leisure activities decreased significantly as the amount of green space per capita increases. How will the economy react to the decrease in usage of pseudo-public spaces will be the determining factor for the future of private-led urbanization. It seems like the shopping malls will continue to struggle with the new measures imposed and the entertainment industry, which was one of the main attractors of the mall will slow down. However, it is still too early to draw the whole picture of how the Covid-19 pandemic will steer debates on "the end of public space".

Within the scope of the study, three inquiries were made that could refer to virtual public space: Virtual space as a leisure activity, virtual space as a shopping space, and virtual space as a meeting/chat platform. It can be read from the survey results that the outbreak reduces interest in virtual spaces as a leisure activity, but it also increases the interest in virtual spaces as a shopping and meeting/chat platform. It is seen that online shopping platforms will largely replace the shopping malls after the outbreak while the traditional bazaar and market will remain. There was a dramatic increase in the use of virtual space as a video meeting/chat platform with the outbreak. The survey results reveal that this trend will continue to a large extent after the outbreak. More importantly, it is observed that there is no significant difference in age in the post-pandemic usage tendency of these platforms, which are mostly used by young people before the pandemic.

Public spaces, which are the heart of cities, are one of the biggest indicators of the urban image. Social sharing is experienced mostly in public spaces. Since the quality of city life can be evaluated from the quality of public spaces, the design and accessibility of these spaces are critical in the city planning agenda. The Covid-19 outbreak temporarily interrupted social life in the city. It caused serious changes in perception and usage of public spaces, which are the basic elements of the city. The longer the outbreak, the greater its impact on the design and planning of public spaces and pseudo-public spaces. Spatial distancing is likely to be included in urban design criteria for public and pseudo-public spaces. Rather than planning huge and crowded spaces such as big squares and huge malls, there is likely a shift toward planning a large number of small-scale public spaces within walking distance. Shopping streets are also possible to replace conventional malls since the residents tend to avoid such places with artificial ventilation. On the other hand, Banerjee's (2001) advice to "engage in advocacy for parks and open spaces" is still valid. According to the study results, planning local parks/active green areas close to residential areas gain importance especially in Istanbul that has already a very low percentage of active green space per capita.

In the first phase of the Covid-19 pandemic, restrictions on the use of public spaces reduced "chance encounters" (Talen 2000) and "social interactions" (Chitrakar 2016), which contributed to the creation of a sense of community. On the other hand, virtual spaces have become more apparent as the new medium of these encounters and interactions. As the pandemic gets longer, the possibility of virtual spaces to change urban habits increases. However, it is also possible to transform the longing for public spaces, especially open green spaces during the outbreak into a tool that promises a higher 
sense of community after the outbreak with the plan and design decisions that increase the quality of public spaces.

Due to circumstances resulted from the ongoing outbreak, the future of public space is uncertain and necessitates more researches from different parts of the world. Especially there is a lack of research regarding field studies in public space usage in Istanbul. This study, which is investigating the possible changes in perception and usage of public spaces and pseudo-public spaces in the city of Istanbul will contribute to the debates on the future of public space in the post-pandemic city. The study is expected to open up new discussions on how public spaces will be transformed and designed in the city of Istanbul as a post-pandemic city.

The survey was conducted between 1 and 5 June 2020 which was right after the first phase of the pandemic. Therefore, the results are likely to reflect the perceptions at that time. If the survey is repeated in the other phases, the results may differentiate. In addition, much of human activity is dependent on weather conditions. Although the mild climate of Istanbul allows the use of open spaces almost throughout the year, the busiest time observed for public spaces in Istanbul is at noon, at the weekend, and in the spring-summer seasons (K1sar 2004). It is clear that there is a need for similar studies covering different phases of the outbreak in Istanbul and in different cases all over the world. In addition, the study indicates that the pandemic may cause radical changes in perception and usage regarding pseudo-public and virtual public spaces. Further studies, which are expected to deepen these inquiries and discuss them in different time periods and cases, will contribute to understanding the shaping and transformation of public space in the post-pandemic city.

\section{References}

AHK Turkey. 2020. Alman-Türk Ticaret ve Sanayi Odası. Koronavirüs: Önlemler. https://www.dtr-ihk.de/tr/koronavirus/oenlemler. Accessed 20 Sept 2020.

Arendt, H. 1998. The Human Condition. Chicago: University of Chicago Press.

Arends, I.S.M., and M.A. Hordijk. 2016. Physical and Virtual Public Spaces for Youth: The Importance of Claiming Spaces in Lima, Peru. In Space, Place, and Environment, ed. K. Nairn, and P. Kraftl, 227-248. Singapore: Springer.

Arslanli, K., T. Unlukara, and V. Dokmeci. 2011. Transformation of Public Spaces in Istanbul. European Planning Studies 19 (6): 1061-1089.

Banerjee, T. 2001. The Future of Public Space: Beyond Invented Streets and Reinvented Places. Journal of the American Planning Association 67 (1): 9-24. https://doi.org/10.1080/01944 360108976352.

Bibeva, I. 2012. Public Space and Its Role for Segregation, Identity and Everyday Life: A Case Study of Östbergahöjden and Its Square. Master's Thesis in Urban and Regional Planning: Stockholm University.

Bodnar, J. 2015. Reclaiming Public Space. Urban Studies 52 (12): 2090-2104. https://doi.org/10.1177/0042098015583626.
Burgers, J. 1995. Public Space in the Post-Industrial Society. Tourism and Spatial Transformations, 147-158. Wallingford: CAB International.

Carr, S., M. Francis, L. Rivlin, and A. Stone. 1992. Public Space. Cambridge: Cambridge University Press.

Çelebi Gürkan, Ü., and N. Özaslan. 2019. Dönüşen Kamusal Mekan: İstanbul-Göktürk Örneği. Journal of International Social Research 12 (62). https://doi.org/10.17719/jisr.2019.3070.

Chitrakar, R.M. 2016. Meaning of Public Space and Sense of Community: The Case of New Neighbourhoods in the Kathmandu Valley. Archnet-Ijar 10 (1): 213-227.

Çöteli, S. 2018. Cyber Public Sphere and Social Movements. Nomos Verlagsgesellschaft mbH \& Co. KG.https://doi. org/10.5771/9783845291260.

CSC. 2020. The Number and GLA (Gross Leasable Area) of Shopping Malls by District. Council of Shopping Centres-Turkey (http://www.ayd.org.tr). Email to Cansu Sözer, 25 June 2020.

Crang, M. 2000. Public Space, Urban Space and Electronic Space: Would the Real City Please Stand Up? Urban Studies 37 (2): 301-317.

Crawford, M. 1999. Blurring the boundaries: Public space and private life. In Everyday Urbanism, ed. J. Chase, M. Crawford, and J. Kaliska, 22-35. New York: TheMonacelli Press.

Dacheux, E. 2012. 'Kamusal Alan: Demokrasinin Anahtar Bir Kavramı'. In Dacheux, E. (eds) Kamusal Alan, (trans: Hüseyin Köse) İstanbul: Ayrıntı Yayınları, pp. 13-27.

Dahlgren, P. 2018. Public Sphere Participation Online: the Ambiguities of Affect'. Les Enjeux de l'information et de la communication 19 (1): 5-20.

Erginli, B. 2018. Services for Children and Family in Istanbul District Municipalities. İstanbul: Tesev Publications. https://www. tesev.org.tr/wp-content/uploads/rapor_istanbu195.rapor_1.pdf. Accessed 15 June 2020.

Francis, J., et al. 2012. Creating Sense of Community: The Role of Public Space. Journal of Environmental Psychology 32 (4): 401-409. https://doi.org/10.1016/j.jenvp.2012.07.002.

Freeman, S. and A. Eykelbosh.2020. COVID-19 and Outdoor Safety: Considerations for Use of Outdoor Recreational Spaces. National Collaborating Centre for Environmental Health.

Fuchs, C. 2017. Social Media: A Critical Introduction. Thousand Oaks: Sage.

Gak, M. 2016. The public sphere: migration of normative principles and the digital construction of transnational ethics. In The Digital Transformation of the Public Sphere: Conflict, Migration, Crisis and Culture in Digital Networks, ed. A. Karatzogianni, D. Nguyen, and E. Serafinelli, 11-33. London: Palgrave Macmillan.

Habermas, J. 1991. The Structural Transformation of the Public Sphere: An Inquiry into a Category of Bourgeois Society. Cambridge: MIT Press.

Honey-Roses, J., I. Anguelovski, J. Bohigas, V. Chireh, C. Daher, and C. Konijnendijk et al. 2020. The Impact of COVID-19 on Public Space: A Review of the Emerging Questions. OSF Preprints.

Karakuyu, M. 2010. İstanbul'un Tarihsel Topoğrafyası ve Literatür Değerlendirmesi. Türkiye Araştırmaları Literatür Dergisi 16: 33-60.

Kısar, E. 2004. Yeşil Alan Kullanım Özellikleri ve Tercihleri (Ataköy, Beşiktaş, Zeytinburnu Örneği). Master's Thesis: Istanbul Technical University.

Kohn, M. 2008. Homo Spectator: Public Space in the Age of the Spectacle. Philosophy \& Social Criticism 34 (5): 467-486. https ://doi.org/10.1177/0191453708089194.

Koramaz, E.K., and H. Türkoğlu. 2014. İstanbul'da kentsel yeşil alan kullanımı ve kentsel yeşil alanlardan memnuniyet. Planlama 24 (1): 26-34.

Kruse, L.M., D.R. Norris, and J.R. Flinchum. 2018. Social Media as a Public Sphere? Politics on Social Media. The Sociological 
Quarterly 59 (1): 62-84. https://doi.org/10.1080/00380 253.2017.1383143.

Langstraat, F., and R. Van Melik. 2013. Challenging the 'End of Public Space': A Comparative Analysis of Publicness in British and Dutch Urban Spaces. Journal of Urban Design 18 (3): 429-448.

Li, S. 2010. The Online Public Space and Popular Ethos in China. Media, Culture \& Society 32 (1): 63-83.

Low, S. M. 2001. The Edge and the Center: Gated Communities and the Discourse of Urban Fear. American Anthropologist 103 (1): 45-58. https://doi.org/10.1525/aa.2001.103.1.45.

Madanipour, A. 2003. Public and Private Spaces of the City. London: Routledge.

Madanipour, A. 2019. Rethinking public space: between rhetoric and reality. URBAN DESIGN International 24 (1): 38-46. https:// doi.org/10.1057/s41289-019-00087-5.

Madden, D. 2010. Revisiting the End of Public Space: Assembling the Public in an Urban Park. City \& Community 9 (2): 187-207. https://doi.org/10.1111/j.1540-6040.2010.01321.x.

Miller, V. 2020. Understanding digital culture. Thousand Oaks: SAGE Publications Limited.

Ministry of Housing, 2020. Covid-19: Safer Public Places- Urban Centres and Green Spaces. London: Government of the United Kingdom. https://www.gov.uk/guidance/safer-public-place s-urban-centres-and-green-spaces-covid-19. Accessed 9 Dec 2020.

Mitchell, D. 1995. The End of Public Space? People's Park, Definitions of the Public, and Democracy. Annals of the Association of American Geographers 85 (1): 108-133. https://doi. org/10.1111/j.1467-8306.1995.tb01797.xa.

Özgür, E.F., et al. 2017. Use of Public Spaces in Private Space-Led Urbanization: The cases of Kadıköy and Ataşehir in İstanbul. AIZ ITU Journal of Faculty of Architecture 14 (1): 43-56. https ://doi.org/10.5505/itujfa.2017.38258.

Paddison, R., and J. Sharp. 2007. Questioning the End of Public Space: Reclaiming Control of Local Banal Spaces. Scottish Geographical Journal 123 (2): 87-106. https://doi. org/10.1080/14702540701615236.

Pratt, A. 2017. The Rise of the Quasi-Public Space and its Consequences for Cities and Culture. Palgrave Communications 3 (1): 1-4. https://doi.org/10.1057/s41599-017-0048-6.
Riether, G. 2016. A Public Space for the Digital Age. In SIGraDi 2016, 20th Conference of the Iberoamerican Society of Digital Graphics, 260-265. Argentina: Buenos Aires.

Sadri, S. 2017. The Scale of Public Space: Taksim Square in Istanbul. Journal of Contemporary Urban Affairs 1 (1): 67-75.

Saylan, S., and E. Erdönmez-Dinçer. 2017. Kamusal Alanların Kullanımında Mekan Kalitesi; Eminönü Mercan Mahallesi. Journal of Urban Academy 10: 29.

Sennett, R. 1977. Fall of Public Man. CUP Archive.

Sorkin, M. 1992. Variations on a Theme Park: The New American City and the End of Public Space. London: Macmillan.

Talen, E. 2000. Measuring the Public Realm: A Preliminary Assessment of the Link Between Public Space and Sense of Community. Journal of Architectural and Planning Research 344-360.

TURKSTAT. 2019. Total Population of Districts, Adress Based Population Recording System (ADNKS) Results. https://birun i.tuik.gov.tr/medas $/$ ?kn=95\&locale=tr. Accessed 25 June 2020.

Varol, A. 2010. Bilgi Toplumunda Kamusal Alan. Sosyal Bilimler Dergisi 1: 121-129.

Voyce, M. 2006. Shopping Malls in Australia: The End of Public Space and the Rise of 'Consumerist Citizenship'? Journal of Sociology 42 (3): 269-286. https://doi.org/10.1177/1440783306 066727.

Wang, Y., and J. Chen. 2018. Does the Rise of Pseudo-Public Spaces Lead to the 'End of Public Space' in Large Chinese Cities? Evidence from Shanghai and Chongqing. URBAN DESIGN International 23 (3): 215-235. https://doi.org/10.1057/s4128 9-018-0064-1.

Weber, M. 1958. The City. Glencoe: Free Press.

Wilson-Doenges, G. 2000. An Exploration of Sense of Community and Fear of Crime in Gated Communities. Environment and Behavior 32 (5): 597-611. https://doi.org/10.1177/0013916002 1972694.

Ye, J. 2019. Re-orienting Geographies of Urban Diversity and Coexistence: Analyzing Inclusion and Difference in Public Space. Progress in Human Geography 43 (3): 478-495.

Publisher's Note Springer Nature remains neutral with regard to jurisdictional claims in published maps and institutional affiliations. 